\title{
Flame-retardant treatment of silk fabric with sodium phytate and chitosan using the layer-by-layer padding technique
}

Oplemenitenje svilene tkanine z ognjeodpornim natrijevim fitatom in hitosanom s pomočjo tehnike impregniranja plast za plastjo

\author{
Original Scientific Article/lzvirni znanstveni članek \\ Received/Prispelo 3-2019 • Accepted/Sprejeto 9-2019
}

\begin{abstract}
Bio-based flame-retardant agents and layer-by-layer assembly have attracted a great deal of attention in the flame-retardant fields of textiles, composites and polymeric materials. In this study, the electrostatic layer-by-layer assembly of chitosan and sodium phytate on silk fabric was carried out using a padding technique. The effects of the concentration and assembled bilayer of chitosan and sodium phytate on the weight gain, flammability, surface morphology, whiteness, stiffness, lustre, tensile strength, and washing durability of silk fabric were studied, and the heat release, thermal stability and flame-retardant mechanism of the coated fabric were analysed. The results revealed that at 10 to 15 assembled bilayers, the coated fabrics exhibited high limiting oxygen indexes and passed the vertical burning test, and their good flame retardancy was maintained even after 15 washing cycles. Moreover, the coated fabrics exhibited a significant decrease in peak the heat release rate and a strong charring ability at high temperatures. The chitosan and sodium phytate system acted as flame retardants in the condensed phase. Given the high weight gain of silk fabric, the layer-by-layer assembly of chitosan and sodium phytate using a padding technique was more applicable to the flame-retardant treatment of furnishing fabrics. Keywords: layer-by-layer, padding, chitosan, sodium phytate, silk, flame-retardancy
\end{abstract}

\section{Izvleček}

Zaviralci gorenja na biološki osnovi in tvorba premaza z nanašanjem plasti za plastjo so pritegnili veliko pozornost na področju ognjevarnih tekstilij, kompozitov in polimernih materialov. V tej raziskavi je bil z uporabo impregnirnega postopka po postopku plast za plastjo na svileno tkanino nanesen elektrostatični premaz hitozana in natrijevega fitata,. Proučevana sta bila vpliva koncentracije in število slojev hitozana in natrijevega fitata na povečanje mase, vnetljivost, morfologijo površine, belino, togost, lesk, natezno trdnost in obstojnost pri pranju svilene tkanine. Analizirani so bili sproščanje toplote, toplotna stabilnost in mehanizem zaviranja gorenja premazane tkanine. Rezultati so pokazali, da so tkanine, prevlečene z 10 do 15 dvoplastmi, imele visok mejni kisikov indeks in so prestale vertikalni test gorenja ter tudi po 15 ciklih pranja ohranile dobro sposobnost zaviranja gorenja. Poleg tega so premazane tkanine pokazale veliko znižanje hitrosti sproščanja toplote in močno sposobnost pooglenitve pri visokih temperaturah. Sistem hitozana in natrijevega fitata je ognjevarno deloval v kondenzirani fazi. Glede na veliko obtežitev svilene tkanine je bil impregnirni postopek nanosa premaza hitozana in natrijevega fitata po postopku plast za plastjo bolj uporaben za ognjevarno obdelavo dekorativnih tkanin.

Ključne besede: plast za plastjo, impregniranje, zaviranje gorenja

Corresponding author/Korespondenčni avtor:

Prof. Dr. Jin-Ping Guan

E-mail: guanjinping@suda.edu.cn
Tekstilec, 2019, 62(4), 269-277

DOI: 10.14502/Tekstilec2019.62.269-277 


\section{Introduction}

Silk, sometimes referred to as the 'Queen of fibres', has a gentle lustre, high moisture and permeability, good comfort and feeling, health care applications and good dry elasticity. It is used widely in a variety of clothing and interior decoration materials. Silk is considered a flammable fibre and has a limit oxygen index (LOI) of around 23-24\%, although it has high nitrogen content. Furnishing silk textiles require a flame-retardant (FR) property. Thus, the FR treatment of silk is required to meet the market requirement of FR silk textiles.

Compared with wool and cotton, there are fewer studies of silk in terms of FR treatment. Silk can be treated using FR agents that are originally used for wool and cotton. These FR agents include fluorotitanate and fluorozirconate, [1] and phosphorusand nitrogen-containing agents [2]. Fluorotitanate and fluorozirconate are applied using a dipping technique, but their washing fastness is inadequate [1]. Most phosphorus- and nitrogen-containing FRs originally used for cotton are resin-type agents, and are applied using a pad-dry-cure process [2]. However, curing at high temperatures gives rise to the deterioration of silk. On the other hand, the effluent discharge of phosphorus compounds during laundering and use causes water eutrophication [3]. Another disadvantage of phosphorus-based and nitrogen-based FRs with methylol groups is formaldehyde release [4]. In addition to the aforementioned FR agents, other FR agents and techniques, such as nano-materials, sol-gel and graft polymerisation, have been studied to enhance the FR properties of silk [5-8].

With the awareness of the toxicity and environmental pollution of FR agents, eco-friendly FR agents and innovative techniques must be used to address existing issues [9]. In this regard, bio-based FR agents such as chitosan $(\mathrm{CH})$, alginates, proteins, and phytic acid or sodium phytate (SP) have been studied to improve the FR properties of textiles [10, 11]. Among them, the use of phytic acid and sodium phytate as FRs has shown great potential because they contain six phosphate groups.

In terms of innovative FR techniques, electrostatic layer-by-layer (LbL) assembly has garnered a great deal of attention $[12,13]$. Electrostatic LbL assembly is usually a self-assembled molecular technique where positively and negatively charged polyelectrolytes spontaneously interact and deposit themselves, primarily via electrostatic forces, to form a membrane. The first study of the application of an LbL assembly in the FR treatment of textiles involved the alternate dipping of silk in $\mathrm{CH}$ and polyphosphoric acid solutions [14]. To date, the LbL assembly that is usually carried out using a repeated dipping approach has been widely studied in the FR finishing of textiles, with the application of a number of oppositely charged substances with FR properties [12]. Among them, $\mathrm{CH}$ and phytic acid and its salts exhibit good FR effects and positive environment benefits because they are naturally-occurring compounds [15-19]. The $\mathrm{CH}$ and phytic acid dip coating at 30 bilayers conferred a self-extinguishing behaviour to cotton fabric with a $16 \%$ increase in fabric weight and a $60 \%$ reduction in the peak heat release rate [17]. However, washing durability was not reported. In addition, a similar dip coating was also applied to polyamide 66 fabric [16]. At 5 to 10 bilayer assemblies with weight increases of $10-15 \%$, the coated fabrics stopped meltdripping, suppressed the spread of flames and decreased the peak heat release rate. The subsequent crossing with sodium tetraborate could obviously improve the washing durability of coated fabrics.

In this study, the electrostatic LbL assembly of $\mathrm{CH}$ and SP on silk fabric was carried out using a padding technique. The effects of the concentration and assembled bilayer of $\mathrm{CH}$ and SP on the weight gain, flammability, surface morphology, whiteness, stiffness, and washing durability of silk fabric were studied. The heat release, thermal stability and FR mechanism of the coated fabric were analysed.

\section{Materials and methods \\ 2.1 Materials}

Silk habotai (fabric code 11206) was obtained from China Jiangsu Huajia Holding Group. The specifications of this fabric are as follows: warp and weft count: 23.3 dtex/2; warp density: 50 threads/cm; weft density: 45 threads/cm; and weight per unit area: 35 $\mathrm{g} / \mathrm{m}^{2}$. Chitosan (purity of $99 \%$ ) $(\mathrm{CH})$ with a molecular weight of 50-100 kDa and a deacetylation degree of around 95\% was purchased from Shandong Western Asia Chemical Industry Inc., China. Sodium phytate (purity of 98\%) (SP) was bought from Shanghai Yuanye Bio-Technology Co. Ltd., China. Sodium hydroxide and acetic acid used for the adjustment of $\mathrm{pH}$ were analytically pure reagents. A commercial 
detergent designed for the household cleaning of silk and wool textiles was purchased from Shanghai Zhengzhang Washing and Dyeing Co., China, and had a solid content of $15.3 \%$ and a $\mathrm{pH}$ of $6.5(2 \mathrm{~g} / \mathrm{L}$ detergent solution).

\subsection{FR coating}

$\mathrm{CH}$ solutions $(0.5 \% \mathrm{wt}$ and $1.0 \% \mathrm{wt})$ were prepared by dissolving $\mathrm{CH}$ in an acetic acid (0.8\% wt) solution. SP solutions of $0.5 \% \mathrm{wt}$ and $1.0 \% \mathrm{wt}$ were also prepared in advance. The $\mathrm{pH}$ of $\mathrm{CH}$ and SP solutions was adjusted to 5 and 4 using acetic acid. Silk fabric was first dipped into a $\mathrm{CH}$ solution, and then squeezed through a roller using a laboratory padder. The fabric prepared as such was dipped into an SP solution, and then squeezed through a roller. During the squeezing, the silk fabric achieved a wet pick-up rate of $100 \%$. After one cycle of padding with $\mathrm{CH}$ and SP solutions, the assembly of the first bilayer (BL) was completed. Later, the assembly process was repeated until the desired number of BLs was achieved. The same concentration $(0.5 \%$ wt or $1.0 \% \mathrm{wt})$ of $\mathrm{CH}$ and SP was used in each LbL assembly. After the completion of assemblies, the coated fabric was dried at $90^{\circ} \mathrm{C}$ in an oven for $2 \mathrm{~min}$.

\subsection{Measurements}

The weight gain of silk fabric was calculated as the difference in the dry weight of the fabric before and after coating. The whiteness of silk fabric was measured according to GB/T 8424.2-2001 using an UltraScan PRO colorimeter (HunterLab, USA). The stiffness of silk fabric in the warp and weft directions was measured according to GB/T 18318-2009 using a YG(B) 022D automatic fabric stiffness tester (Wenzhou Darong Textile Instrument Co. Ltd., China), while the tensile strength of silk fabric in the warp and weft directions was measured using an Instron 5967 tester (Illinois Tool Works Inc., USA) according to GB/T 3923.2-2013. Before testing, samples were placed in an atmospheric environment of $65 \%$ relative humidity and $20{ }^{\circ} \mathrm{C}$ for 24 hours. The average result of five specimens was used for each sample. The lustre of silk fabric was characterised using the reflectivity of light measured by a Gonio Photometer GP-200 (Murakami Color Research Laboratory Co. Ltd., Japan) in the following conditions: incident angle: $60^{\circ}$; and light-reflection angle: $-90^{\circ}$ to $90^{\circ}$. The average result of five specimens was reported. The surface morphological structures of coated silk fabrics were observed using a TM-3030 type scanning electron microscope (SEM) (Hitachi, Japan) at an acceleration voltage $5 \mathrm{kV}$.

The flammability of silk fabric was evaluated using LOI and vertical burning tests. The LOI of silk fabric was measured using an FTT0080 oxygen index apparatus (Fire Testing Technology Ltd., UK) according to the ASTM D2863 Standard Test Method. The vertical burning of silk fabric was conducted using a YG815B automatic vertical flammability cabinet (Ningbo Textile Instrument Factory, China) according to the ASTM D6413 Standard Test Method. A pyrolysis combustion flow calorimetry (PCFC) analysis was performed using a FTT0001 microscale combustion calorimetry (Fire Testing Technology Ltd., UK) according to the ASTM D7309 Standard Test Method. The thermogravimetry (TG) analysis of silk fabric (about 5-6 mg) was conducted using a TG/DSC 5700 thermal analyser (PerkinElmer) at a heating rate of $10{ }^{\circ} \mathrm{C} / \mathrm{min}$ in the temperature range of 30 to $600{ }^{\circ} \mathrm{C}$ under a nitrogen flow of $100 \mathrm{~mL} / \mathrm{min}$.

The washability of coated fabric was tested using an XW-ZDR-25X12 low-noise oscillating dyeing machine (Jingjiang Xinwang dyeing and finishing equipment factory, China) using $2 \mathrm{~g} / \mathrm{L}$ commercial detergent and a bath ratio of 50:1. Each washing cycle was performed at $40{ }^{\circ} \mathrm{C}$ for $30 \mathrm{~min}$.

\section{Results and discussion \\ 3.1 Weight gain and surface morphology of coated silk fabric}

As shown in Figure 1, the weight gain of silk fabric increased with an increase in the number of assembly layers at two concentrations of CH/SP. Except for the experimental point at $1.0 \% \mathrm{CH} / \mathrm{SP}$ and $20 \mathrm{BLs}$, two sets of experimental points showed a good linear correlation between weight gain and assembly layers. Varying weight gain resulted in different FR parameter values, as discussed later. This indicates the possibility that assembly layers and $\mathrm{CH} / \mathrm{SP}$ concentration can be selected according to requirements for the weight gain and FR properties of silk fabrics. At this point, several weight-gain points should be mentioned. As $0.5 \% \mathrm{CH} / \mathrm{SP}$ was used, the weight gain of silk fabric was $13.66 \%$ and $21.46 \%$ at 10 and $15 \mathrm{BL}$ assemblies, respectively. At $1.0 \% \mathrm{CH} / \mathrm{SP}$ and $10 \mathrm{BL}$ assemblies, the weight gain was $24.81 \%$. 


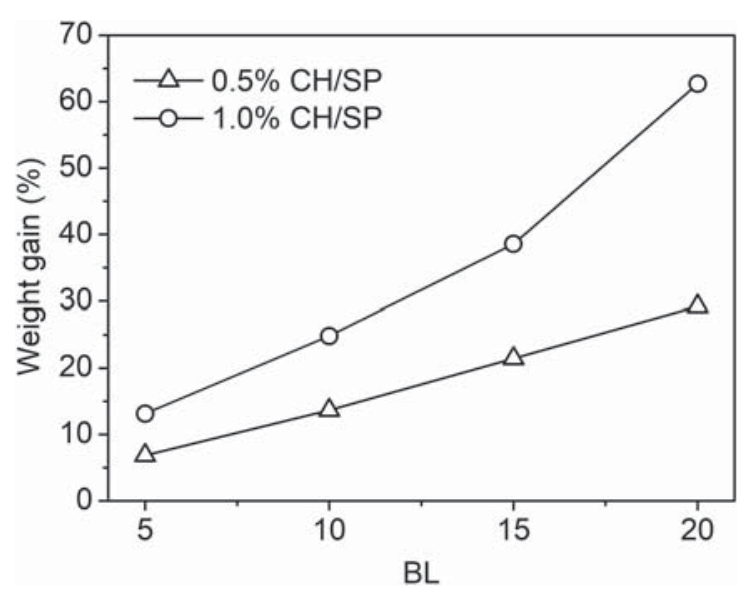

Figure 1: Weight gain of silk fabrics obtained using two concentrations of $\mathrm{CH} / \mathrm{SP}$ at different BLs

After dip coating, the surface morphology of silk fabric showed different degrees of change, as shown in Figure 2. The untreated fabric had a smooth surface. As assembly layers and $\mathrm{CH} / \mathrm{SP}$ concentration increased, more deposits were found on the fabric surface, and accumulated between fibres. At $0.5 \%$ $\mathrm{CH} / \mathrm{SP}$ and $20 \mathrm{BLs}$, and at $1.0 \% \mathrm{CH} / \mathrm{SP}$ and 15 and 20 BLs, fibre bundles could not be observed (images not shown) due to excessive deposits of $\mathrm{CH} / \mathrm{SP}$ on the fabric surface. The surface coatings can confer positive fire-protection properties to silk fabric, as discussed later.

\subsection{Flammability of coated silk fabric}

LOI and vertical burning tests were used to evaluate the flammability of silk fabrics. In the LOI test (Figure 3), as the assembled layers increased, the LOI of silk fabric increased (LOI was 23\% for original silk). Several experimental points were given: LOI was $29.4 \%$ and $30.7 \%$ at $0.5 \% \mathrm{CH} / \mathrm{SP}$ at 10 and 15 BLs, respectively; at $1.0 \% \mathrm{CH} / \mathrm{SP}$ and $10 \mathrm{BLs}$, the weight gain was $32.2 \%$. Increasing $\mathrm{CH} / \mathrm{SP}$ concentration and BLs further increased LOI relative to the points described above.

In the vertical burning test, the original silk fabric burned quickly and was completely burned within the ignition time (12 s), producing a char length of $30 \mathrm{~cm}$, and thus had no after-flame time and afterglow time. As shown Figure 3, the coated fabrics at two concentrations of CH/SP had a char length of less than $15 \mathrm{~cm}$ when the number of assembly layers was equal to or greater than $10 \mathrm{BLs}$, indicating that they meet the B1 level requirement of FR decorative fabrics for char length according to $\mathrm{GB} / \mathrm{T}$ 17591-2006, where the char length must be less than $15 \mathrm{~cm}$. However, the fabrics assembled at 5 BLs could not pass the vertical burning test because of their long char length. The photos presented in Figure 4 further illustrate the visual results of vertical burning. At the same BLs, the fabrics coated with a high concentration of $\mathrm{CH} / \mathrm{SP}$ showed smaller burned areas and shorter char length.
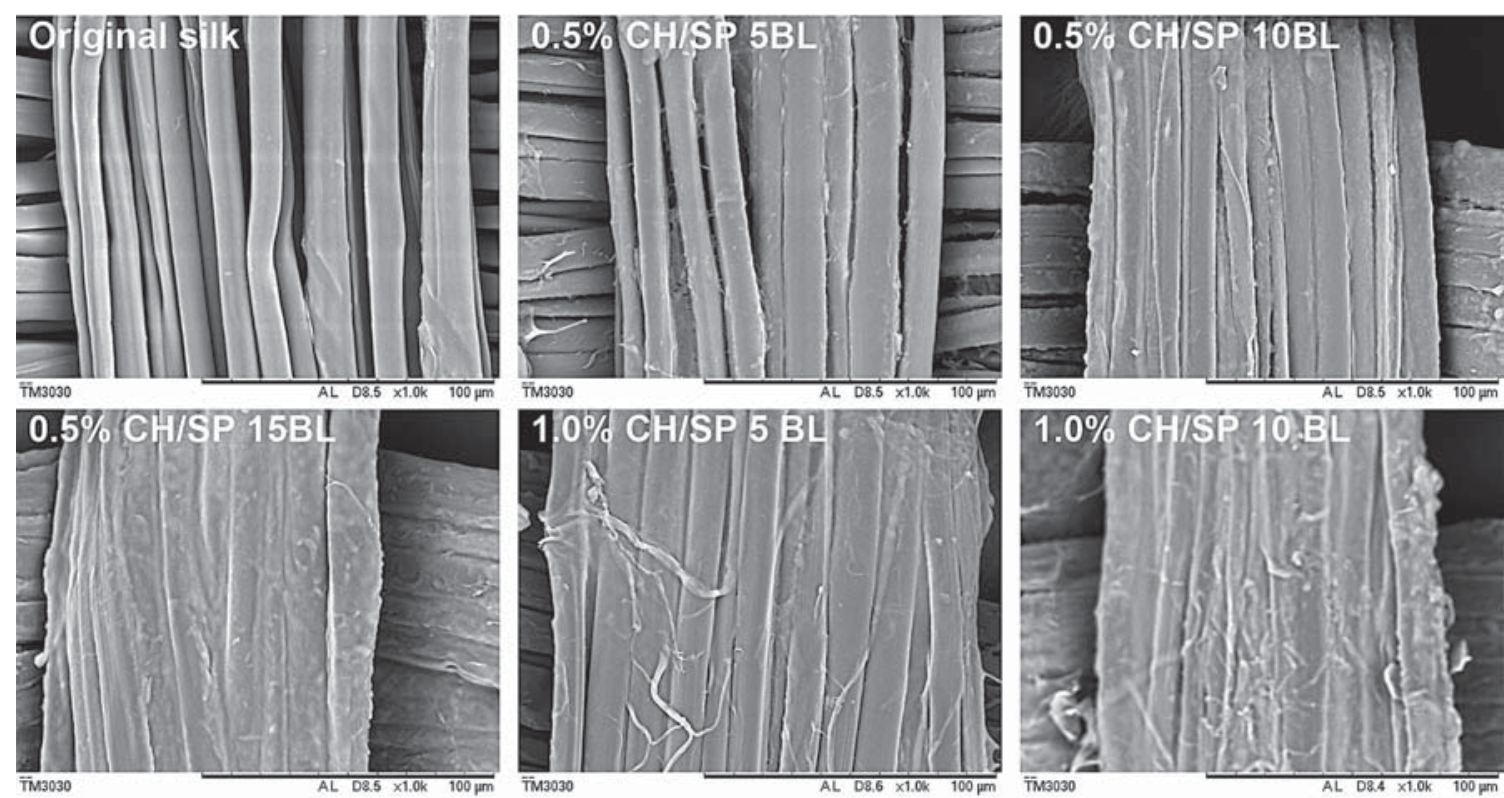

Figure 2: SEM images of silk fabrics obtained using two concentrations of $C H / S P$ at different BLs 


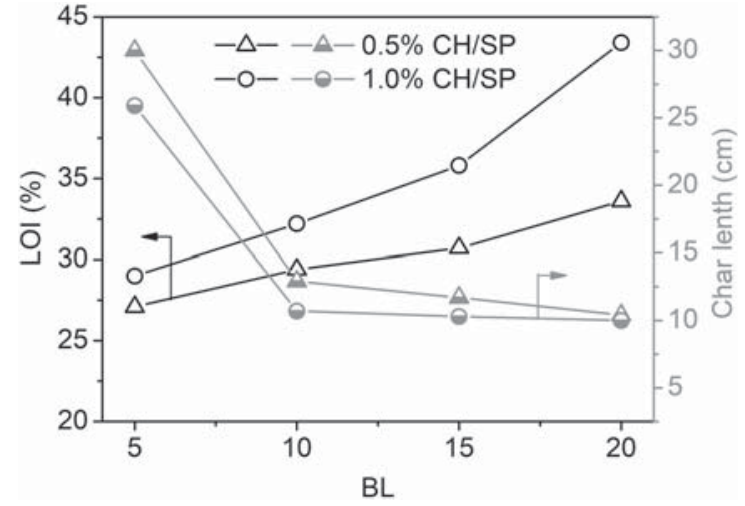

Figure 3: LOI and char length of silk fabrics obtained using two concentrations of $\mathrm{CH} / \mathrm{SP}$ at different $\mathrm{BLS}$

(a) $0.5 \% \mathrm{CH} / \mathrm{SP}$

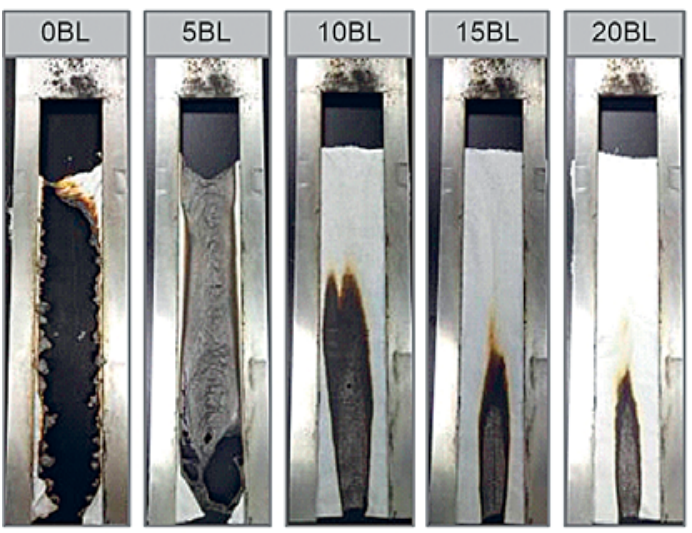

(b) $1.0 \% \mathrm{CH} / \mathrm{SP}$

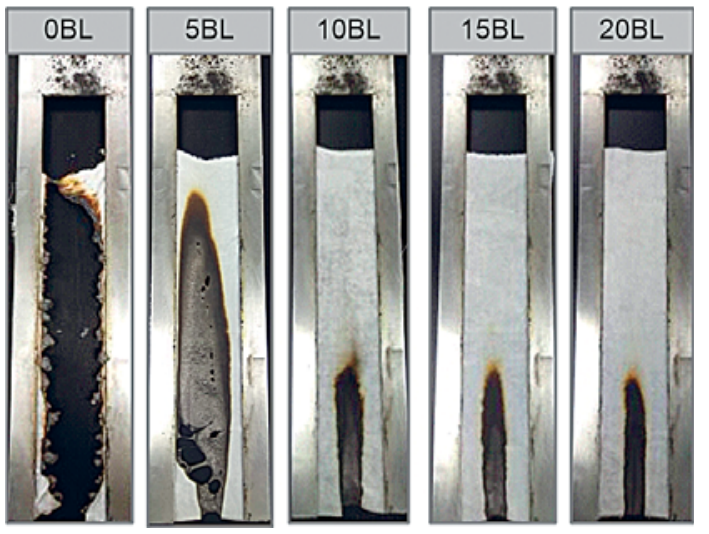

Figure 4: Vertical burning results of silk fabrics obtained using two concentrations of $C H / S P$ at different $B L s$

\subsection{Whiteness, stiffness, lustre and tensile strength of coated silk fabric}

SP has a slightly yellow appearance, and the yellowing of SP occurs during heating due to oxidation [20].
These factors would affect the colour of the coated fabric. In addition, the advantages of silk include its soft touch and gentle lustre. The coating of $\mathrm{CH}$ polymer on the surface of silk thus has a negative effect on the softness and lustre of silk fabric. The whiteness, stiffness and lustre of coated silk fabric were therefore evaluated.

Figure 5 shows that there was an obvious decrease in whiteness with an increase in $\mathrm{CH} / \mathrm{SP}$ concentration and assembled BLs. Taking this into account, an excessively high concentration of $\mathrm{CH} /$ $\mathrm{SP}$ and a high number of assembled BLs should be avoided.

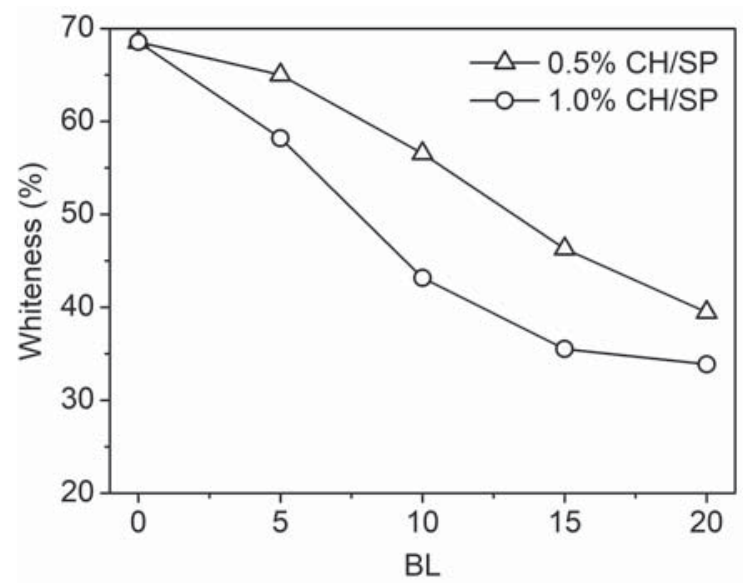

Figure 5: Whiteness of silk fabrics obtained using two concentrations of $\mathrm{CH} / \mathrm{SP}$ at different BLs

Figure 6 shows that the stiffness of silk fabric increased greatly as the concentration of $\mathrm{CH} / \mathrm{SP}$ and the number of assembled BLs were increased. In the case of $0.5 \% \mathrm{CH} / \mathrm{SP}, 5$ and $10 \mathrm{BL}$ assemblies had a

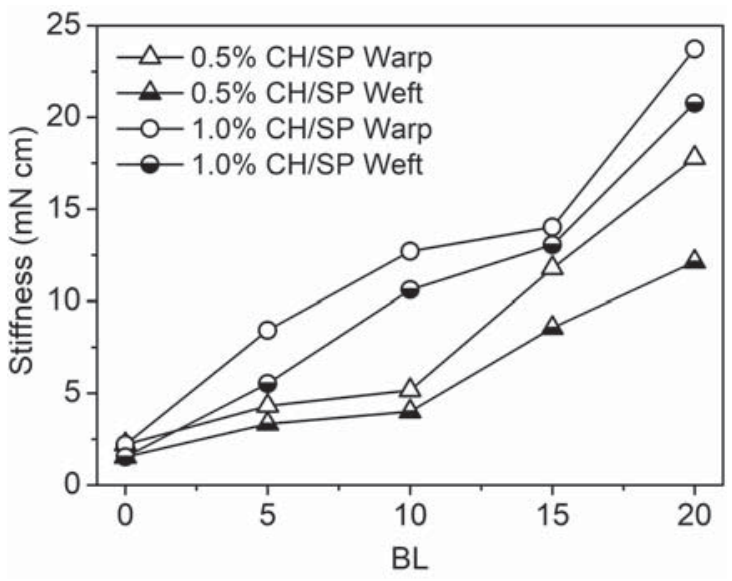

Figure 6: Stiffness of silk fabrics obtained using two concentrations of $\mathrm{CH} / \mathrm{SP}$ at different $\mathrm{BLs}$ 
relatively small effect on the stiffness of silk fabric. Taking into account both stiffness and FR properties (Figures 3 and 4), an excessively high concentration of CH/SP and a high number of assembled BL should also be avoided. Here it should be noted that the decreased softness of silk fabric caused by FR coating is sometimes a disadvantage and sometimes an advantage, depending on the applications of silk fabric. For example, the use of silk fabrics as tablecloths, sofa fabrics, wall furnishing fabrics, jackets, etc. usually requires decreased softness or increased stiffness. Thus, the coated fabrics obtained using the present approach can meet the requirement for increased stiffness. The proper weight gain and stiffness can be determined according to the results of Figures 1 and 6 and the end-uses of silk fabrics.

Figure 7 shows that the reflectivity of silk fabric, as an expression of its lustre, decreased considerably as the concentration of $\mathrm{CH} / \mathrm{SP}$ and the number of assembled BLs increased, due to an increase in the roughness of fabric surface on account of deposits of $\mathrm{CH}$ polymer. The decrease in the lustre of silk fabric is a disadvantage of the present LbL assembly.

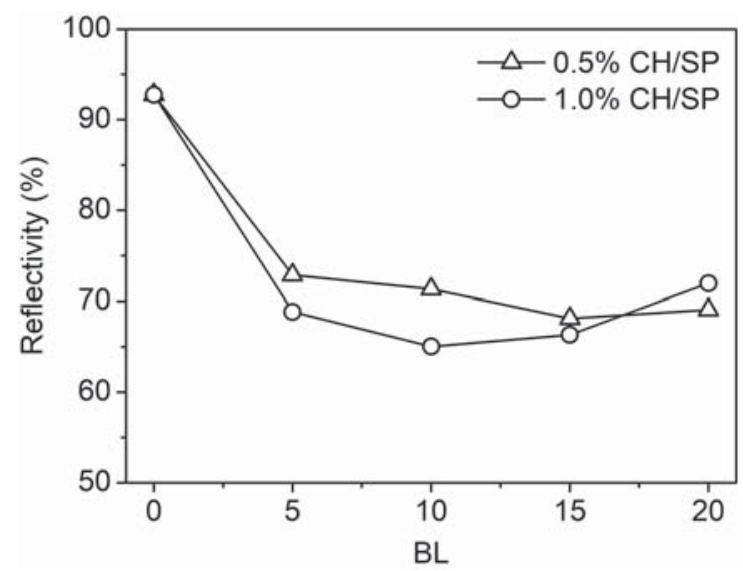

Figure 7: Light reflectivity of silk fabrics obtained using two concentrations of CH/SP at different BLs

The tensile strength of silk fabric was also measured. As shown in Figure 8, the tensile strength of silk fabric in the warp and weft directions increased significantly with an increase in the concentration of $\mathrm{CH} / \mathrm{SP}$ and the number of assembled BLs. This is associated with the reinforcement effect of $\mathrm{CH}$ polymer. Increased tensile strength would be beneficial for the application of silk fabric in decorative materials.

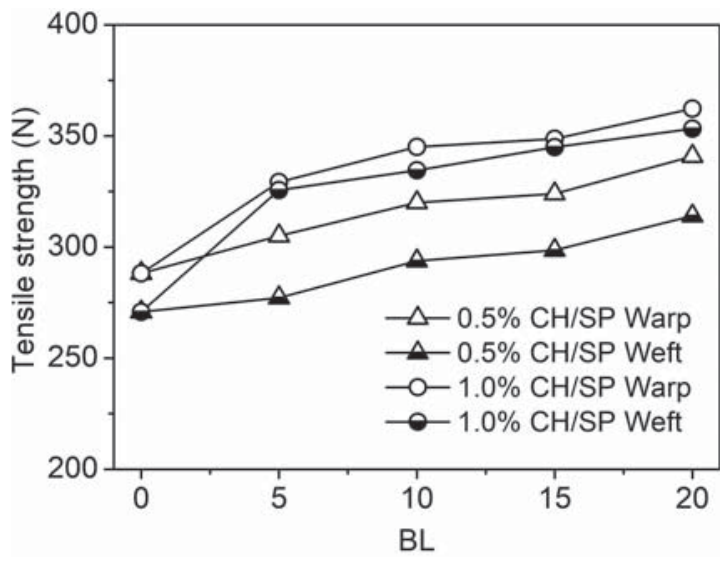

Figure 8: Tensile strength of silk fabrics obtained using two concentrations of $C H / S P$ at different $B L s$

\subsection{Washing durability of coated silk fabric}

Silk fabrics for furnishings are subjected to different degrees of washing, depending on the end-uses of fabrics. The washing durability of the coated silk fabric was thus evaluated. Figure 9 shows that the LOI of the coated fabric gradually decreased with an increase in the number of washing cycles. The decrease in LOI was related to the LOI of the unwashed sample or $\mathrm{CH} /$ SP concentration and assembled BLs. After 15 washing cycles, all samples still had a char length of less than $15 \mathrm{~cm}$, and passed the vertical burning test for the B1 level. It was worthy of noting that the samples obtained using 0.5\% CH/SP and $15 \mathrm{BLs}$ and $1.0 \% \mathrm{CH} /$ SP and 10 BLs exhibited high LOI, even after 10 or 15 washing cycles, indicating their good washing durability. The good washing durability of coatings is associated with in situ formation and the insolubilisation of $\mathrm{CH} / \mathrm{SP}$ polyelectrolytes on the surface of silk $[17,21]$.

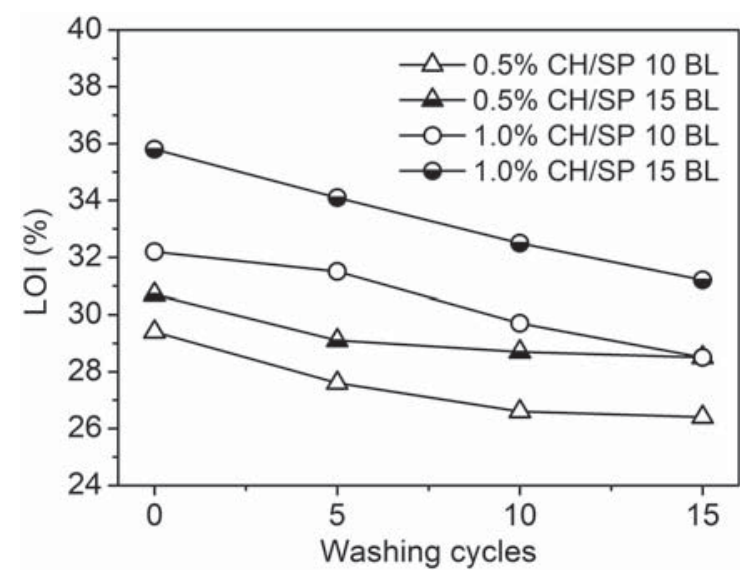

Figure 9: Washing durability of silk fabrics obtained using two concentrations of CH/SP at 10 and $15 \mathrm{BLs}$ 


\subsection{PCFC analysis of coated silk fabric}

A microcalorimeter was further used to evaluate the flammability of silk fabric. A sample of several milligrams was required for the PCFC analysis. The sample was first pyrolyzed in nitrogen. The volatile products were then mixed with oxygen and burned in a combustion zone in order to measure the combustion heat of pyrolysis products [22]. Several flammability parameters were obtained, including the heat release rate (HRR), total heat release (THR), heat release capacity (HRC), the peak heat release rate (pHRR), temperature at maximum heat release rate $\left(T_{\max }\right)$ and char residue yield. Figure 10 shows the measured HRR values of silk fabrics as a function of temperature, while Table 1 lists the associated PCFC parameters.

Figure 10 shows that the HRR of the coated fabrics decreased in the temperature range of $300{ }^{\circ} \mathrm{C}$ to $500{ }^{\circ} \mathrm{C}$ and that the $T_{\max }$ shifted to a lower temperature (also see Table 1) compared to that of the original sample. The decreased $T_{\max }$ of the coated fabrics is due to the lower initial thermal stability of $\mathrm{CH}$ and SP $[20,23]$. It is evident from Table 1 that the coated fabrics exhibited significant decreases in HRR, THR and HRC, indicating their low heat release

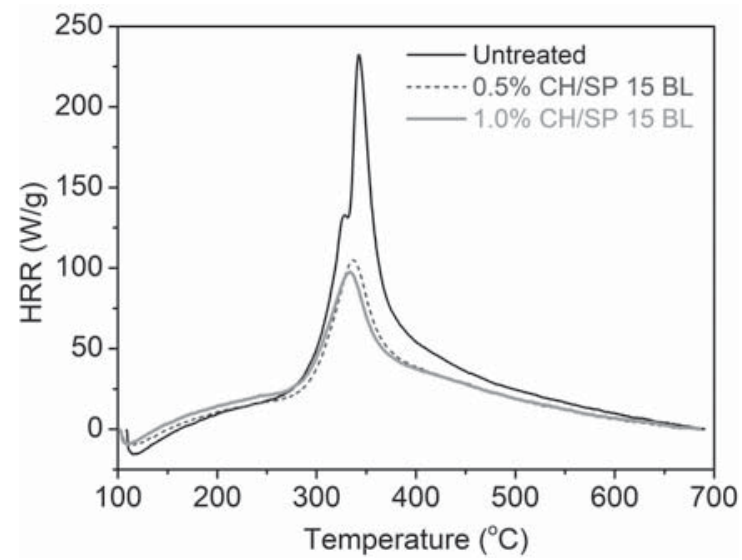

Figure 10: Heat release rate curves of silk fabrics obtained using two concentrations of CH/SP at $15 \mathrm{BL}$ during combustion. Such fabrics would represent a low fire hazard [24]. Moreover, the coated fabrics yielded higher char amounts in the heat pyrolysis than the original sample. This implies the reduced volatility of products and the formation of thermal protection layers. The latter can inhibit the further burning of polymeric substrates and thus lead to the enhanced FR properties of the fabrics.

\subsection{Thermal stability of coated silk fabric}

The TG curves of silk fabrics are shown in Figure 11. The weight loss process of uncoated silk was divided into three stages: the first stage where the loss of adsorbed water occurred before $250{ }^{\circ} \mathrm{C}$; the second stage where that loss occurred between $250^{\circ} \mathrm{C}$ and $350{ }^{\circ} \mathrm{C}$, which represents a major thermal decomposition of silk causing the splitting of protein chains; and the third stage where that loss occurred above $350{ }^{\circ} \mathrm{C}$, which represents the further pyrolysis of degraded products. The residual weight was around $27 \%$ at $600{ }^{\circ} \mathrm{C}$.

After coating, silk displayed significant changes in weight loss. Decreased weight loss occurred below $310^{\circ} \mathrm{C}$. One important reason for this is that $\mathrm{CH}$ has a higher degradation below $300{ }^{\circ} \mathrm{C}$ than the original

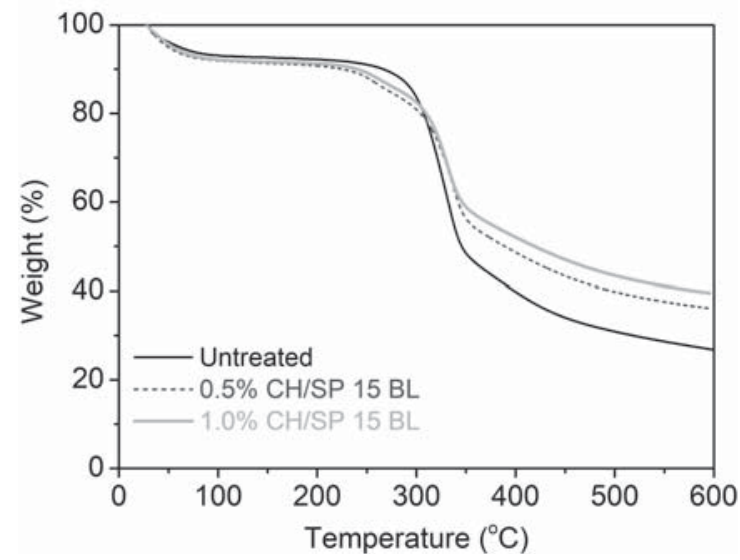

Figure 11: TG curves in nitrogen of silk fabrics obtained using two concentrations of CH/SP at $15 \mathrm{BL}$

Table 1: PCFC parameters of silk fabrics obtained using two concentrations of $\mathrm{CH} / \mathrm{SP}$ at $15 \mathrm{BL}$

\begin{tabular}{|c|c|c|c|c|c|c|}
\hline $\begin{array}{c}\mathrm{CH} / \mathrm{SP} \text { conc. } \\
(\% \mathrm{wt})\end{array}$ & $\mathrm{BL}$ & $\begin{array}{c}\mathrm{pHRR} \\
(\mathrm{W} / \mathrm{g})\end{array}$ & $\begin{array}{c}\mathrm{HRC} \\
\left(\mathrm{Jg}^{-1} \mathrm{~K}^{-1}\right)\end{array}$ & $\begin{array}{c}\mathrm{THR} \\
(\mathrm{KJ} / \mathrm{g})\end{array}$ & $\begin{array}{c}T_{\max } \\
\left({ }^{\circ} \mathrm{C}\right)\end{array}$ & $\begin{array}{c}\text { Char yield } \\
(\%)\end{array}$ \\
\hline 0 & 0 & 232.4 & 251 & 17.9 & 342.7 & 26.58 \\
\hline 0.5 & 15 & 105.1 & 112 & 12.3 & 336.5 & 37.89 \\
\hline 1.0 & 15 & 97.5 & 105 & 12.8 & 333.4 & 39.30 \\
\hline
\end{tabular}


silk $[23,25]$. Above $310^{\circ} \mathrm{C}$, the coated fabrics exhibited lower weight loss than the original silk. There were two reasons for this. One reason is the good thermal stability of the degraded products of $\mathrm{CH}$ and SP on silk at high temperatures $[23,26]$. The other reason is that SP containing six phosphate groups is a charring agent that promotes the dehydration and char forming of silk. At $600{ }^{\circ} \mathrm{C}$, the residual weight of the fabrics coated with $0.5 \%$ and $1.0 \% \mathrm{CH} / \mathrm{SP}$ was $36 \%$ and $40 \%$, respectively. This correlates well with those in the PCFC analysis (Table 1).

Taking into account the results of the PCFC and TG analyses, it can be concluded that the CH/SP FR system acts in the solid phase by catalysing the charring of silk and thus providing thermal protection layers during combustion.

\section{Conclusion}

The FR modification of silk fabric with $\mathrm{CH}$ and SP was performed using a LbL padding assembly. With regard to the weight gain, FR properties, whiteness, stiffness and washing durability of coated fabrics, the assemblies using $0.5 \% \mathrm{CH} / \mathrm{SP}$ at 10 and $15 \mathrm{BLs}$ and $1.0 \% \mathrm{CH} / \mathrm{SP}$ at $10 \mathrm{BLs}$ were good selections. The resulting fabrics exhibited good FR properties, as indicated by LOI and vertical combustion tests, and could be subjected to more than 15 cycles of washing. The PCFC and TG analyses revealed that the condensed phase FR mechanism was suitable for coated fabrics. Because of the high weight increase of coated fabrics, the present LbL approach seemed to be more suitable for the FR finishing of decorative silk textiles.

\section{Acknowledgements}

This study was funded by the Jiangsu Provincial Key Research and Development Program of China (BE2015066) and the Priority Academic Program Development (PAPD) of Jiangsu Higher Education Institutions (No. 2014-37).

\section{References}

1. ZHANG, Xibiao, ZHOU, Xian-You, CHENG, Xian-Wei, TANG, Ren-Cheng. Phytic acid as an eco-friendly flame retardant for silk/wool blend: A comparative study with fluorotitanate and fluorozirconate. Journal of Cleaner Production, 2018, 198, 1044-1052, doi: 10.1016/j.jclepro. 2018.07.103.

2. GUAN, Jinping, YANG, Charles Q, CHEN, Guoqiang. Formaldehyde-free flame retardant finishing of silk using a hydroxyl-functional organophosphorus oligomer. Polymer Degradation and Stability, 2009, 94(3), 450-455, doi: 10.1016/j.polymdegradstab.2008.10.024.

3. LEE, G. Fred. Role of phosphorus in eutrophication and diffuse source control. Water Research, 1973, 7, 111-128, doi: 10.1016/00431354(73)90156-5.

4. ŠEHIĆ, Alisa, TAVČER, Petra Forte, SIMONČIČ, Barbara. Flame retardants and environmental issues. Tekstilec, 2016, 59(3), 196-205, doi: 10.14502/Tekstilec2016.59.196-205.

5. CHAIWONG, C., TUNMA, S., SANGPRASERT, W., NIMMANPIPUG, P., BOONYAWANAB, D. Graft polymerization of flame-retardant compound onto silk via plasma jet. Surface and Coatings Technology, 2010, 204(18-19), 2991-2995, doi: 10.1016/j.surfcoat.2010.02.044.

6. CHENG, Xian-Wei, GUAN, Jin-Ping, YANG, $\mathrm{Xu}-\mathrm{Hong}$, TANG, Ren-Cheng. Improvement of flame retardancy of silk fabric by bio-based phytic acid, nano- $\mathrm{TiO}_{2}$, and polycarboxylic acid. Progress in Organic Coatings, 2017, 112, 18-26, doi: 10.1016/j.porgcoat.2017.06.025.

7. GUAN, Jinping, CHEN, Guoqiang. Flame resistant modification of silk fabric with vinyl phosphate. Fibers and Polymers, 2008, 9(4), 438-443, doi: 10.1007/s12221-008-0070-9.

8. LIU, Chun, XING, Tieling, WEI, Bingju, CHEN, Guoqiang. Synergistic effects and mechanism of modified silica sol flame retardant systems on silk fabric. Materials, 2018, 11(10), 1842, doi: 10.3390/ma11101842.

9. ALONGI, Jenny, CAROSIO, Federico, MALUCELLI, Giulio. Current emerging techniques to impart flame retardancy to fabrics: an overview. Polymer Degradation and Stability, 2014, 106, 138149, doi: 10.1016/j.polymdegradstab.2013.07.012.

10. COSTES, Lucie, LAOUTID, Fouad, BROHEZ, Sylvain, DUBOIS, Philippe. Bio-based flame retardants: When nature meets fire protection. Materials Science and Engineering R, 2017, 117, 1-25, doi: 10.1016/j.mser.2017.04.001.

11. MALUCELLI, Giulio, BOSCO, Francesca, ALONGI, Jenny, CAROSIO, Federico, Di BLASIO, 
Alessandro, MOLLEA, Chiara, CUTTICA, Fabio, CASALE, Annalisa. Biomacromolecules as novel green flame retardant systems for textiles: an overview. RSC Advances, 2014, 4(86), 4602446039, doi: 10.1039/c4ra06771a.

12. HOLDER, Kevin M., SMITH, Ryan J., GRUNLAN, Jaime C. A review of flame retardant nanocoatings prepared using layer-by-layer assembly of polyelectrolytes. Journal of Materials Science, 2017, 52(22), 12923-12959, doi: 10. 1007/s10853-017-1390-1.

13. MALUCELLI, Giulio. Surface-engineered fire protective coatings for fabrics through sol-gel and layer-by-layer methods: an overview. Coatings, 2016, 6(3), 33, doi: 10.3390/coatings6030033.

14. SRIKULKIT, Kawee, IAMSAMAI, Chularat, DUBAS, Stephan T. Development of flame retardant polyphosphoric acid coating based on the polyelectrolyte multilayers technique. Journal of Metals, Materials and Minerals, 2006, 16(2), 41-45.

15. CAROSIO, Federico, Di BLASIO, Alessandro, ALONGI, Jenny, MALUCELLI, Giulio. Green DNA-based flame retardant coatings assembled through layer by layer. Polymer, 2013, 54(19), 5148-5153, doi: 10.1016/j.polymer.2013.07.029.

16. KUNDU, Chanchal K., WANG, Xin, SONG, Lei, HU, Yuan. Borate cross-linked layer-by-layer assembly of green polyelectrolytes on polyamide 66 fabrics for flame-retardant treatment. Progress in Organic Coatings, 2018, 121, 173181, doi: 10.1016/j.porgcoat.2018.04.031.

17. LAUFER, Galina, KIRKLAND, Christopher, MORGAN, Alexander B, GRUNLAN, Jaime C. Intumescent multilayer nanocoating, made with renewable polyelectrolytes, for flame-retardant cotton. Biomacromolecules, 2012, 13(9), 28432848, doi: 10.1021/bm300873b.

18. LI, Zhong-Fang, ZHANG, Chuan-Jie, CUI, Li, ZHU, Ping, YAN, Chao, LIU, Yun. Fire retardant and thermal degradation properties of cotton fabricsbased on APTES and sodium phytate through layer-by-layer assembly. Journal of Analytical and Applied Pyrolysis, 2017, 123, 216223, doi: 10.1016/j.jaap.2016.11.026.

19. LIU, Juan, XIAO, Congming. Fire-retardant multilayer assembled on polyester fabric from water-soluble chitosan, sodium alginate and divalent metal ion. International Journal of $\mathrm{Bi}$ ological Macromolecules, 2018, 119, 1083-1089, doi: 10.1016/j.ijbiomac.2018.08.043.

20. DANELUTI, André Luis Máximo, MATOS do ROSÁRIO, Jivaldo. Study of thermal behavior of phytic acid. Brazilian Journal of Pharmaceutical Sciences, 2013, 49(2), 275-283, doi: 10.1590/ S1984-82502013000200009.

21. ZHANG, Tao, YAN, Hongqiang, SHEN, Lie, FANG, Zhengping, ZHANG, Xianming, WANG, Jiajun, ZHANG, Baoyue. Chitosan/phytic acid polyelectrolyte complex: a green and renewable intumescent flame retardant system for ethylene-vinyl acetate copolymer. Industrial and Engineering Chemistry Research, 2014, 53(49), 19199-19207, doi: 10.1021/ie503421f.

22. ALONGI, Jenny, CUTTICA, Fabio, CAROSIO, Federico, BOURBIGOT, Serge. How much the fabric grammage may affect cotton combustion? Cellulose, 2015, 22(5), 3477-3489, doi: 10.1007/ s10570-015-0717-9.

23. ZHANG, Sheng, LIU, Xiaodong, JIN, Xiaodong, LI, Hongfei, SUN, Jun, GU, Xiaoyu. The novel application of chitosan: effects of cross-linked chitosan on the fire performance of thermoplastic polyurethane. Carbohydrate Polymers, 2018, 189, 313-321, doi: 10.1016/j.carbpol.2018.02.034.

24. LYON, Richard E., WALTERS, R. N., STOLIAROV, S. I. Screening flame retardants for plastics using microscale combustion calorimetry. Polymer Engineering and Science, 2007, 47(10), 1501-1510, doi: 10.1002/pen.20871.

25. LV, Zhong, HU, Yi-Ting, GUAN, Jin-Ping, TANG, Ren-Cheng, CHEN, Guo-Qiang. Preparation of a flame retardant, antibacterial, and colored silk fabric with chitosan and vitamin B2 sodium phosphate by electrostatic layer by layer assembly. Materials Letters, 2019, 241, 136-139, doi: 10.1016/j.matlet.2019.01.005.

26. PAN, Ying, ZHAN, Jing, PAN, Haifeng, WANG, Wei, TANG, Gang, SONG, Lei, HU, Yuan. Effect of fully biobased coatings constructed via layer-by-layer assembly of chitosan and lignosulfonate on the thermal, flame retardant, and mechanical properties of flexible polyurethane foam. ACS Sustainable Chemistry and Engineering, 2016, 4(3), 1431-1438, doi: 10.1021/ acssuschemeng.5b01423. 